\title{
Five-year direct medical costs and comorbidities after bariatric surgery of obese patients with type 2 diabetes mellitus: A population-based propensity score-matched study
}

\section{Tingting Wu}

University of Hong Kong

Simon Kin Hung Wong

Chinese University of Hong Kong

Betty Tsz Ting Law

Queen Mary Hospital

Eleanor Grieve

University of Glasgow Institute of Health and Wellbeing

\section{Olivia Wu}

University of Glasgow Institute of Health and Wellbeing

Daniel King Hung Tong

Hong Kong Sanatorium and Hospital

David Kai Wing Leung

United Christian Hospital

\section{Enders Kwok Wai Ng}

Chinese University of Hong Kong

Cindy Lo Kuen Lam

University of Hong Kong

Carlos King-Ho Wong ( $\nabla$ carlosho@hku.hk)

The University of Hong Kong https://orcid.org/0000-0002-6895-6071

\section{Original investigation}

Keywords: Bariatric surgery, Comorbidities, Cost, Healthcare utilization, Obesity, Type 2 Diabetes

Posted Date: March 9th, 2020

DOI: https://doi.org/10.21203/rs.3.rs-16320/v1

License: (a) This work is licensed under a Creative Commons Attribution 4.0 International License. Read Full License 
Version of Record: A version of this preprint was published on September 29th, 2020. See the published version at https://doi.org/10.1002/bjs.11970. 


\section{Abstract}

Background: Bariatric surgery is effective in weight reduction and diabetes remission. This study aimed to estimate direct medical costs and changes of comorbidities after bariatric surgery up to five years among obese patients with type 2 diabetes mellitus.

Methods: A population-based retrospective cohort of obese type 2 diabetes patients from Hong Kong Hospital Authority between 2006 and 2017 was assembled. One-to-five propensity score matching method was applied to match 401 eligible surgical patients with 1,894 non-surgical patients. Frequency of healthcare service utilization and dispense of diabetes medication were collected for both groups to estimate the direct medical costs from baseline to up to 60 months; Charlson Comorbidity Index (CCl) and number of comorbidities were measured to compare the changes of comorbidities between two groups over the 5 years.

Results: Direct medical costs were US\$40,889 for surgical patients and US\$6,163 for controls in the index year $(p<0.001)$, with incremental costs of US $\$ 34,726$. Bariatric surgery and hospitalization were the main cost drivers for surgical patients in the year of surgery. Although surgical patients had significantly lower annual costs than control patients in the subsequent four years, five-year cumulative costs incurred by surgical patients were significantly greater than controls (US $\$ 60,174$ vs US $\$ 33,374, p<0.001$ ), regardless of subgroups. Surgical patients had better profile of comorbidities than controls, as they had significantly lower $\mathrm{CCl}$ after baseline and fewer percentages of them proceeded to higher $\mathrm{CCl}$ categories.

Conclusions: Over 5 years, bariatric surgery was associated with increased medical costs in the year of surgery and cumulative costs. Although bariatric surgery is not cost-saving for type 2 diabetes patients at 5 years, it is associated with improved comorbidity profile.

\section{Background}

As populations aging and lifestyles change, the prevalence of obesity and obesity-related diseases, such as type 2 diabetes mellitus, continues to increase worldwide[1]. The prevalence of obesity since 1980 has doubled in over 70 countries [2] and, the global number of patients with type 2 diabetes mellitus is projected to rise sharply from 451 million in 2017 to 693 million in 2045 [3]. The economic burden of both obesity and obesity-related metabolic disorders is consequently exerting great pressure on health care systems everywhere $[4,5]$.

While lifestyle interventions are considered as the first-line treatment for obese patients with type 2 diabetes mellitus [6], these modalities are often limited by unsustainable and modest effects on weight reduction and disease remission [7]. As a consequence, bariatric surgery has been widely accepted as the most effective therapy for the treatment of morbid obesity [8] and as a useful option to resolve type 2 diabetes mellitus [9-11] and reduce the risks of cardiovascular diseases (CVD) and mortality. Guidelines 
for the management of obesity and/or type 2 diabetes mellitus recommended that bariatric surgery should be considered or recommended for obese patients with certain health conditions [12-14]. In recent years, there has been a rapid growth in bariatric surgery globally [15]. This increase, however, has inevitably accelerated the need for long-term support and nutritional follow-up, bariatric surgery-related hospitalization and use of other healthcare services [16].

Reported unit cost of bariatric procedures ranged between US\$7,423 and US\$33,541, with a mean of US\$14,389 [17]. However, the mean cost of lifestyle intervention achieving one kilogram of weight loss varied from only US\$54 over a 2-month period to US\$1,005 over twelve months [18]. Despite the expensive unit cost of bariatric procedure, costs associated with bariatric surgery mainly accrued at the year of the surgery and reduced during the post-surgery period. Patients with bariatric surgery may have reduced costs of prescription, outpatient visits and/or hospitalization in the long-term, since obesityrelated complications and loss of productivity averted after surgery [19-22]. It was found that most economic evaluations of bariatric surgery were conducted in the US [20-22], however, it should be carefully performed anywhere else where the healthcare system differs inherently from the US and the burden of obesity and obesity-related diseases is substantial.

In this regard, this study aimed to 1) estimate five-year cumulative and annual direct medical costs of obese type 2 diabetes patients with and without undergoing bariatric surgery in overall and by subgroups; 2) examine the patterns of healthcare service use and dispense of diabetes medications among surgical and non-surgical patients over a five-year period; and 3) compare the profiles of comorbidities between bariatric surgery patients and control patients from baseline to up to 5 years.

\section{Methods}

\section{Study Design and Study Population}

The study design and population were described previously [23]. In brief, a population-based retrospective cohort study of obese patients with type 2 diabetes who had ever utilized public healthcare services between January 2006 and December 2017 was assembled from the Clinical Management System (CMS) managed by Hong Kong Hospital Authority (HA). Patients who had undertaken bariatric surgery were extracted by a pre-defined list of International Classification of Disease, Ninth Revision, Clinical Modification (ICD-9-CM) procedure codes, while type 2 diabetes and other comorbidities were identified through ICD-9-CM diagnosis codes and International Classification of Primary Care version 2 (ICPC-2) codes (Supplemental Table 1). Surgical patients were excluded if they underwent non-bariatric procedural operations, did not have pre-existing type 2 diabetes, had no body mass index (BMI) readings or had BMI 
reading $<27.5 \mathrm{~kg} / \mathrm{m}^{2}$ [24] at the index date (i.e. the date of bariatric surgery). A one-to-five propensity score matching method was used to match each eligible surgical patient with up to 5 non-surgical patients. The index date of non-surgical patients was same as that of their matched surgical patients. Ethics approval of this study was granted by Institutional Review Board of the University of Hong Kong /Hospital Authority Hong Kong West Cluster (Ref No. UW 16-1018). Consent was not obtained as the data were analyzed anonymously.

\section{Outcomes}

Primary outcomes were the five-year cumulative and annual direct medical costs of obese type 2 diabetes patients with and without bariatric surgery in overall and by subgroups, as well as changes of comorbidity profile of both groups over five years. Secondary outcomes were the frequency and costs of use of healthcare services and diabetes medications.

\section{Estimation of annual direct medical costs}

The dates and frequency of the use of HA healthcare services by patients in the surgery and matched control group in the index year and subsequent four years were retrieved. Healthcare services included general outpatient clinics (GOPC), specialist outpatient clinics (SOPCs), accident and emergency (A\&E) and allied health professionals (including clinical psychologists, dietitians, occupational therapists, physiotherapists, and smoking counselling and cessation visits), as were as length of hospitalization in a general ward, intensive care unit (ICU), cardiac care unit (CCU) and high dependency unit (HDU). Unit costs of healthcare services were extracted from the public charges to non-eligible persons listed in the 2017 Government Gazette and HA Ordinance (Chap. 113) [25]. Additionally, for bariatric surgery patients, the unit cost of bariatric and revision procedures were estimated based on the private charges for operations (mid-point value) listed in HA website [26] and personal communications with bariatric surgeons.

Types of anti-diabetic drugs prescribed and days supply of each dispensed anti-diabetic drugs at each clinic visit during the follow-up period were also collected. Included diabetes medications were insulin, metformin, thiazolidinedione (TZD), dipeptidyl peptidase 4 inhibitors (DPP-4i), sodium glucose cotransporter 2 inhibitors (SGLT2i), and glucagon-like peptide-1 (GLP-1) receptor agonists. Costs of diabetes medications per 30-day supply were based on a published paper [27], and the midpoints of the cost range of each class of diabetes medication were used to estimate the medication costs.

The pegged exchange rage of US\$1 = HK\$7.80 was used to convert Hong Kong dollars to the US dollar. Supplemental table 2 summarizes the unit cost of healthcare services and diabetes medications.

Supplemental table 2

The annual direct medical costs for each patient were calculated based on the formula:

Annual direct medical costs $=\left(\sum\right.$ frequency of the healthcare service use in that year $\cdot$ unit cost of the respective healthcare service $)+\left(\sum\right.$ days supply of diabetes medication $\cdot$ midpoint cost of the cost range 


\section{Changes of comorbidities}

Numbers of patients with different comorbidities (including hypertension, mental health problems, hyperlipidemia, obstructive sleep apnea, gallbladder disease, musculoskeletal and chronic orthopedic disorders, CVD, severe hypoglycemia, chronic lung diseases, chronic renal disease [CRD]) and percentage of patients in different $\mathrm{CCl}$ categories $(1,2,3,4,5$ or above, dead) were measured from baseline to up to 60 months. Also, changes of mean CCls of two groups from baseline to 5 years were visualized in line graphs, and trends of mean $\mathrm{CCl}$ changes were analyzed for both groups through tests for trends.

\section{Statistical analysis}

\section{Baseline covariates}

The baseline covariates of patients included gender, age, BMl, and pre-existing of complications (including hypertension, mental health problems, hyperlipidemia, obstructive sleep apnea, gallbladder disease, musculoskeletal and chronic orthopedic disorders, CVD, and CRD).

\section{Propensity Score Matching Method}

Multiple imputation by chained equations (MICE) [28] was used to address the absence of baseline data. $\mathrm{HbA}_{1 \mathrm{c}}$, blood pressure and low-density lipoprotein cholesterol were imputed by gender, BMl, history of comorbidities (i.e. hypertension, mental health problems, hyperlipidemia, obstructive sleep apnea, gallbladder disease, musculoskeletal and chronic orthopedic disorders and CVD), duration of type 2 diabetes, $\mathrm{CCl}$, and use of insulin and oral anti-diabetic drugs. Model parameters were estimated from multiple imputed data and then were used to obtain multiple-imputation linear predictions by applying Rubin's combination rules observation wise to the completed-data predictions [29], where twenty imputed datasets were created for multiple imputations. Obtained predictions were then used in propensity score matching.

Each patient's propensity score was computed by multivariable logistic regression adjusting for baseline covariates of patient. The caliper criteria improved the quality of the nearest neighbor matching by specifying a maximum tolerance of the propensity score distance between patients in the surgical group and in the control group. The propensity score matching was performed by 'calipmatch' command on a one-to-five basis without replacement in STATA.

Baseline socio-demographic, clinical parameters and comorbidities of patients in both groups were presented by frequency with percentages for categorical variables and means with SD for continuous variables. Independent t-tests or chi-square tests were used to assess the difference in the baseline characteristics between the two groups. Balance of baseline covariates between two groups after matching was measured by standardized mean difference (SMD). All SMDs less than 0.2 implied optimal balance between the two groups [30]. 


\section{Generalized linear models}

Direct estimation of annual cost using normal Gaussian distribution may be problematic due to the skewness of the data and zero-cost issues [31]. Therefore, generalized linear models (GLMs) with gamma family and log-link were used to accurately estimate the five-year cumulative and annual direct medical costs. GLMs, especially the gamma regression model, perform well on the estimation of non-negative and positively skewed cost data [32], and the model has been widely used in analyses of medical costs [33, 34]. The GLM goodness of fit was tested by using the Modified Park Test [35]. According to Modified Park Test [35], a model coefficient approximating to 2 indicated that the use of gamma distribution in GLMs was preferred.

The mean frequency and cost of visiting different types of healthcare services from the index year up to the fifth year in both groups of patients was reported and visualized in line graphs. Estimated five-year annual direct medical costs and their SDs were calculated in overall and by subgroups. Considered subgroups were gender, age group ( $<60 \mathrm{vs} \geq 60$ years old), BMl category ( $<35 \mathrm{vs} \geq 35 \mathrm{~kg} / \mathrm{m}^{2}$ ), duration of type 2 diabetes history ( $\leq 5 \mathrm{vs}>5$ years), CCl category ( $<4 \mathrm{vs} \geq 4)$, history of CVD and CRD. Annual costs alongside cumulative costs were presented in figures.

All statistical analyses were performed by STATA Version 13.1 (StataCorp LP, College Station, Texas). All significance tests were two-tailed and a p-value of $<0.05$ was considered as statistically significant.

\section{Results}

\section{Sample characteristics}

A total of 422 obese type 2 diabetes patients met the criteria to take part in the surgery group. After propensity score matching, a cohort of 2,295 patients (401 surgical patients and 1,894 non-matched controls) were included in current analysis (Supplemental Fig. 1).

The baseline characteristics between two groups were well balanced (Supplemental Fig. 2 and Supplemental Table 3). The mean BMI of surgery and control patients were $36.81 \mathrm{~kg} / \mathrm{m}^{2}$ and $36.31 \mathrm{~kg} / \mathrm{m}^{2}$, respectively $(p=0.121, \mathrm{SMD}=0.090)$. Of 401 surgical patients, $299(74.6 \%)$ underwent laparoscopic sleeve gastrectomy, 74 (18.5\%) underwent laparoscopic gastric bypass, 11 (2.7\%) underwent laparoscopic adjustable gastric banding, and 17 (4.2\%) underwent laparoscopic sleeve gastrectomy with duodenojejunal bypass

\section{Frequency and costs of use of healthcare services}

The mean number of outpatient visits for both groups was between 6 and 10 visits, and the control group had significantly fewer outpatient visits than surgical patients across five years. The mean number of A\&E visits for both groups was smaller than one; and the differences were insignificant over 5 years, except in year 2 (Surgery: 0.48 , Control: $0.84, p<0.001$ ). The mean number of allied health professional 
visits made by the matched control patients was around one, and surgical patients had more allied health professional visits than non-surgical patients across the five years except in year 4 . Patients in the bariatric surgery group had longer mean length of stays in hospital wards (16.8 nights) than the nonsurgical patients $(4.4$ nights) in the index year $(p<0.001)$. However, surgical patients had shorter length of hospital stay than non-surgical patients, and the differences were significant in year 2 and 4. (Fig. 1)

For both groups, the largest component of annual direct medical costs was inpatient services in the first year, followed by outpatient services, allied health professional visits, and A\&E visits. (Supplemental Fig. 3)

\section{Dispensing days and costs of glucose-lowering medications}

Annual total medication costs were stable for control patients, fluctuating between US\$1,525 and US $\$ 1,723$. In contrast, medication costs of surgical patients in the first 2 years after the surgery nearly halved, from US $\$ 1,909$ to US $\$ 1,078$. In the subsequent years, the costs increased gradually and reached to US\$2,079 at year 5. It was found that surgical patients had higher glucose-lowering medication costs than control patients in year 1 and 5 , but had lower costs in year 2 to 4 . However, the differences were not significant, except in year 2 when medication costs of surgical patients were higher than those of nonsurgical patients (US\$1,078 vs. US $\$ 1,562, p=0.010$ ). Of note, prescribed insulin in the bariatric surgery group reduced greatly over the years. (Supplemental Table 4)

Supplemental Table 4

\section{Estimated annual and cumulative direct medical cost}

The coefficients of GLM constructed for predicting medical costs in each year were 1.44, 1.96, 1.96, 2.05, and 1.87, indicating that the use of GLMs with gamma family and log link in our dataset were generally supported.

Figure 2 shows the annual and cumulative direct medical costs in overall and by subgroups. Overall, the direct medical costs of the bariatric surgery group in the year of surgery was US\$40,889 (SD US\$26,053), which was nearly seven times the cost of the matched control group (US\$6,163, SD US\$5,639) ( $p<$ 0.001). Bariatric surgery incrementally raised the medical costs of obese patients with type 2 diabetes by US\$34,726 in the index year. However, surgical patients tended to have significantly lower medical costs in the following 4 years, with medical costs ranged from US\$4,581 (SD US\$4,228) to US\$5,201 (SD US\$7,361). The medical costs of matched control group was relatively stable through the index year to year 5, fluctuating between US\$6,163 (SD US\$5,639) and US\$7,882 (SD US\$9,695).

In exploratory analysis, surgical patients in each subgroup had significantly higher medical costs than non-surgical patients in the year of bariatric surgery (all $p<0.001$ ). During the remaining four years, annual costs of surgical patients were no more than the costs of their non-surgical counterparts in the same subgroup. 
During the five-year follow-up period, cumulative costs of US\$60,174 (SD US\$41,066) and US\$33,374 (SD US $\$ 36,870)$ were incurred by surgical patients and non-surgical $(p<0.001)$, respectively. Similar pattern that surgical patients had significant higher cumulative medical costs was also found in subgroups, except for patients with pre-existing CRD. Expenditures on medical costs incurred by patients with poorer health conditions (e.g. greater age, longer duration of type 2 diabetes, more number of comorbidities, and presence of CVD and CRD) were greater than their counterparts. Of note, cumulative medical costs of patients with a history of CRD exceeded US\$200,000 over the five years, ranking the first among patients in other subgroups.

\section{Changes of comorbidity profiles}

Table 1 lists the number and percentage of patients with different comorbidities over the years. Over the 60 months, less percentage of surgical patients newly developed hypertension, hyperlipidemia, musculoskeletal and chronic orthopedic disorders, CVD, severe hypoglycemia, chronic lung disease and CRD. Figure 3 portrays the mean $\mathrm{CCl}$ of both groups from baseline to 60 months. Mean $\mathrm{CCl}$ of both groups were similar at the baseline, however, surgical patients had significantly lower mean $\mathrm{CCl}$ than control patients in the subsequent years. Although the mean $\mathrm{CCl}$ of surgical patients increased from 3.40 to 3.82 , the $\mathrm{p}$ for trend was 0.443 , indicating the change of $\mathrm{CCl}$ was stable for surgical patients. In contrast, the $p$-trend of control patients was smaller than 0.001 . 
Table 1

Number and percentages of patients with comorbidities at baseline and follow-ups

\begin{tabular}{|c|c|c|c|c|c|c|c|}
\hline $\begin{array}{l}\text { Comorbidities, N } \\
\text { (\%) }\end{array}$ & Baseline & $12 \mathrm{~m}$ & $24 m$ & $36 \mathrm{~m}$ & $48 \mathrm{~m}$ & $60 \mathrm{~m}$ & $\begin{array}{l}\text { Absolute } \\
\text { percentage } \\
\text { increase } \\
\text { over } 60 \mathrm{~m}\end{array}$ \\
\hline \multicolumn{8}{|l|}{ Surgery $(N=401)$} \\
\hline Hypertension & $\begin{array}{l}319 \\
(79.6 \%)\end{array}$ & $\begin{array}{l}327 \\
(81.5 \%)\end{array}$ & $\begin{array}{l}328 \\
(81.8 \%)\end{array}$ & $\begin{array}{l}329 \\
(82 \%)\end{array}$ & $\begin{array}{l}329 \\
(82 \%)\end{array}$ & $\begin{array}{l}330 \\
(82.3 \%)\end{array}$ & $2.7 \%$ \\
\hline $\begin{array}{l}\text { Mental health } \\
\text { problems }\end{array}$ & $\begin{array}{l}21 \\
(5.2 \%)\end{array}$ & $\begin{array}{l}27 \\
(6.7 \%)\end{array}$ & $\begin{array}{l}29 \\
(7.2 \%)\end{array}$ & $\begin{array}{l}30 \\
(7.5 \%)\end{array}$ & $\begin{array}{l}30 \\
(7.5 \%)\end{array}$ & $\begin{array}{l}32 \\
(8.0 \%)\end{array}$ & $2.7 \%$ \\
\hline Hyperlipidemia & $\begin{array}{l}205 \\
(51.1 \%)\end{array}$ & $\begin{array}{l}219 \\
(54.6 \%)\end{array}$ & $\begin{array}{l}220 \\
(54.9 \%)\end{array}$ & $\begin{array}{l}223 \\
(55.6 \%)\end{array}$ & $\begin{array}{l}226 \\
(56.4 \%)\end{array}$ & $\begin{array}{l}227 \\
(56.6 \%)\end{array}$ & $5.5 \%$ \\
\hline $\begin{array}{l}\text { Obstructive sleep } \\
\text { apnea }\end{array}$ & $\begin{array}{l}220 \\
(54.9 \%)\end{array}$ & $\begin{array}{l}227 \\
(56.6 \%)\end{array}$ & $\begin{array}{l}230 \\
(57.4 \%)\end{array}$ & $\begin{array}{l}230 \\
(57.4 \%)\end{array}$ & $\begin{array}{l}232 \\
(57.9 \%)\end{array}$ & $\begin{array}{l}233 \\
(58.1 \%)\end{array}$ & $3.2 \%$ \\
\hline Gallbladder disease & $\begin{array}{l}34 \\
(8.5 \%)\end{array}$ & $\begin{array}{l}39 \\
(9.7 \%)\end{array}$ & $\begin{array}{l}41 \\
(10.2 \%)\end{array}$ & $\begin{array}{l}41 \\
(10.2 \%)\end{array}$ & $\begin{array}{l}42 \\
(10.5 \%)\end{array}$ & $\begin{array}{l}44 \\
(11.0 \%)\end{array}$ & $2.5 \%$ \\
\hline $\begin{array}{l}\text { Musculoskeletal } \\
\text { and chronic } \\
\text { orthopedic } \\
\text { disorders }\end{array}$ & $\begin{array}{l}98 \\
(24.4 \%)\end{array}$ & $\begin{array}{l}104 \\
(25.9 \%)\end{array}$ & $\begin{array}{l}109 \\
(27.2 \%)\end{array}$ & $\begin{array}{l}110 \\
(27.4 \%)\end{array}$ & $\begin{array}{l}111 \\
(27.7 \%)\end{array}$ & $\begin{array}{l}113 \\
(28.2 \%)\end{array}$ & $3.7 \%$ \\
\hline \multicolumn{8}{|l|}{$\begin{array}{l}\text { Cardiovascular } \\
\text { diseases }\end{array}$} \\
\hline $\begin{array}{l}\text { Acute myocardial } \\
\text { infarction }\end{array}$ & $8(2.0 \%)$ & $\begin{array}{l}9 \\
(2.2 \%)\end{array}$ & $\begin{array}{l}9 \\
(2.2 \%)\end{array}$ & $\begin{array}{l}10 \\
(2.5 \%)\end{array}$ & $\begin{array}{l}11 \\
(2.7 \%)\end{array}$ & $\begin{array}{l}11 \\
(2.7 \%)\end{array}$ & $0.7 \%$ \\
\hline $\begin{array}{l}\text { Other ischemic } \\
\text { heart disease }\end{array}$ & $\begin{array}{l}29 \\
(7.2 \%)\end{array}$ & $\begin{array}{l}30 \\
(7.5 \%)\end{array}$ & $\begin{array}{l}31 \\
(7.7 \%)\end{array}$ & $32(8 \%)$ & $\begin{array}{l}33 \\
(8.2 \%)\end{array}$ & $\begin{array}{l}33 \\
(8.2 \%)\end{array}$ & $1.0 \%$ \\
\hline $\begin{array}{l}\text { Congestive heart } \\
\text { failure }\end{array}$ & $\begin{array}{l}15 \\
(3.7 \%)\end{array}$ & $\begin{array}{l}17 \\
(4.2 \%)\end{array}$ & $\begin{array}{l}17 \\
(4.2 \%)\end{array}$ & $\begin{array}{l}17 \\
(4.2 \%)\end{array}$ & $\begin{array}{l}17 \\
(4.2 \%)\end{array}$ & $\begin{array}{l}17 \\
(4.2 \%)\end{array}$ & $0.5 \%$ \\
\hline Stroke & $\begin{array}{l}17 \\
(4.2 \%)\end{array}$ & $\begin{array}{l}18 \\
(4.5 \%)\end{array}$ & $\begin{array}{l}18 \\
(4.5 \%)\end{array}$ & $20(5 \%)$ & $\begin{array}{l}21 \\
(5.2 \%)\end{array}$ & $\begin{array}{l}23 \\
(5.7 \%)\end{array}$ & $1.5 \%$ \\
\hline $\begin{array}{l}\text { Peripheral vascular } \\
\text { disease }\end{array}$ & $\begin{array}{l}10 \\
(2.5 \%)\end{array}$ & $\begin{array}{l}11 \\
(2.7 \%)\end{array}$ & $\begin{array}{l}11 \\
(2.7 \%)\end{array}$ & $\begin{array}{l}11 \\
(2.7 \%)\end{array}$ & $\begin{array}{l}11 \\
(2.7 \%)\end{array}$ & $\begin{array}{l}11 \\
(2.7 \%)\end{array}$ & $0.2 \%$ \\
\hline $\begin{array}{l}\text { Severe } \\
\text { hypoglycemia }\end{array}$ & $\begin{array}{l}64 \\
(16 \%)\end{array}$ & $\begin{array}{l}71 \\
(17.7 \%)\end{array}$ & $\begin{array}{l}72 \\
(18 \%)\end{array}$ & $\begin{array}{l}73 \\
(18.2 \%)\end{array}$ & $\begin{array}{l}74 \\
(18.5 \%)\end{array}$ & $\begin{array}{l}75 \\
(18.7 \%)\end{array}$ & $2.7 \%$ \\
\hline $\begin{array}{l}\text { Chronic lung } \\
\text { disease }\end{array}$ & $12(3 \%)$ & $\begin{array}{l}13 \\
(3.2 \%)\end{array}$ & $\begin{array}{l}14 \\
(3.5 \%)\end{array}$ & $\begin{array}{l}14 \\
(3.5 \%)\end{array}$ & $\begin{array}{l}14 \\
(3.5 \%)\end{array}$ & $\begin{array}{l}15 \\
(3.7 \%)\end{array}$ & $0.7 \%$ \\
\hline $\begin{array}{l}\text { Chronic renal } \\
\text { disease }\end{array}$ & $5(1.2 \%)$ & $\begin{array}{l}6 \\
(1.5 \%)\end{array}$ & $\begin{array}{l}6 \\
(1.5 \%)\end{array}$ & $\begin{array}{l}6 \\
(1.5 \%)\end{array}$ & $\begin{array}{l}7 \\
(1.7 \%)\end{array}$ & $\begin{array}{l}7 \\
(1.7 \%)\end{array}$ & $0.5 \%$ \\
\hline
\end{tabular}




\begin{tabular}{|c|c|c|c|c|c|c|c|}
\hline $\begin{array}{l}\text { Comorbidities, N } \\
\text { (\%) }\end{array}$ & Baseline & $12 \mathrm{~m}$ & $24 \mathrm{~m}$ & $36 \mathrm{~m}$ & $48 \mathrm{~m}$ & $60 \mathrm{~m}$ & $\begin{array}{l}\text { Absolute } \\
\text { percentage } \\
\text { increase } \\
\text { over } 60 \mathrm{~m}\end{array}$ \\
\hline \multicolumn{8}{|l|}{ Control $(\mathrm{N}=1894)$} \\
\hline Hypertension & $\begin{array}{l}1464 \\
(77.3 \%)\end{array}$ & $\begin{array}{l}1489 \\
(78.6 \%)\end{array}$ & $\begin{array}{l}1520 \\
(80.3 \%)\end{array}$ & $\begin{array}{l}1532 \\
(80.9 \%)\end{array}$ & $\begin{array}{l}1545 \\
(81.6 \%)\end{array}$ & $\begin{array}{l}1549 \\
(81.8 \%)\end{array}$ & $4.5 \%$ \\
\hline $\begin{array}{l}\text { Mental health } \\
\text { problems }\end{array}$ & $\begin{array}{l}112 \\
(5.9 \%)\end{array}$ & $\begin{array}{l}125 \\
(6.6 \%)\end{array}$ & $\begin{array}{l}131 \\
(6.9 \%)\end{array}$ & $\begin{array}{l}137 \\
(7.2 \%)\end{array}$ & $\begin{array}{l}139 \\
(7.3 \%)\end{array}$ & $\begin{array}{l}144 \\
(7.6 \%)\end{array}$ & $1.7 \%$ \\
\hline Hyperlipidemia & $\begin{array}{l}960 \\
(50.7 \%)\end{array}$ & $\begin{array}{l}1014 \\
(53.5 \%)\end{array}$ & $\begin{array}{l}1063 \\
(56.1 \%)\end{array}$ & $\begin{array}{l}1094 \\
(57.8 \%)\end{array}$ & $\begin{array}{l}1113 \\
(58.8 \%)\end{array}$ & $\begin{array}{l}1120 \\
(59.1 \%)\end{array}$ & $8.4 \%$ \\
\hline $\begin{array}{l}\text { Obstructive sleep } \\
\text { apnea }\end{array}$ & $\begin{array}{l}1041 \\
(55.0 \%)\end{array}$ & $\begin{array}{l}1054 \\
(55.6 \%)\end{array}$ & $\begin{array}{l}1063 \\
(56.1 \%)\end{array}$ & $\begin{array}{l}1068 \\
(56.4 \%)\end{array}$ & $\begin{array}{l}1077 \\
(56.9 \%)\end{array}$ & $\begin{array}{l}1079 \\
(57 \%)\end{array}$ & $2.0 \%$ \\
\hline Gallbladder disease & $\begin{array}{l}140 \\
(7.4 \%)\end{array}$ & $\begin{array}{l}145 \\
(7.7 \%)\end{array}$ & $\begin{array}{l}151 \\
(8 \%)\end{array}$ & $\begin{array}{l}153 \\
(8.1 \%)\end{array}$ & $\begin{array}{l}155 \\
(8.2 \%)\end{array}$ & $\begin{array}{l}156 \\
(8.2 \%)\end{array}$ & $0.8 \%$ \\
\hline $\begin{array}{l}\text { Musculoskeletal } \\
\text { and chronic } \\
\text { orthopedic } \\
\text { disorders }\end{array}$ & $\begin{array}{l}483 \\
(25.5 \%)\end{array}$ & $\begin{array}{l}519 \\
(27.4 \%)\end{array}$ & $\begin{array}{l}549 \\
(29 \%)\end{array}$ & $\begin{array}{l}585 \\
(30.9 \%)\end{array}$ & $\begin{array}{l}601 \\
(31.7 \%)\end{array}$ & $\begin{array}{l}620 \\
(32.7 \%)\end{array}$ & $7.2 \%$ \\
\hline \multicolumn{8}{|l|}{$\begin{array}{l}\text { Cardiovascular } \\
\text { diseases }\end{array}$} \\
\hline $\begin{array}{l}\text { Acute myocardial } \\
\text { infarction }\end{array}$ & $\begin{array}{l}42 \\
(2.2 \%)\end{array}$ & $\begin{array}{l}49 \\
(2.6 \%)\end{array}$ & $\begin{array}{l}51 \\
(2.7 \%)\end{array}$ & $\begin{array}{l}60 \\
(3.2 \%)\end{array}$ & $\begin{array}{l}63 \\
(3.3 \%)\end{array}$ & $\begin{array}{l}69 \\
(3.6 \%)\end{array}$ & $1.4 \%$ \\
\hline $\begin{array}{l}\text { Other ischemic } \\
\text { heart disease }\end{array}$ & $\begin{array}{l}196 \\
(10.3 \%)\end{array}$ & $\begin{array}{l}208 \\
(11 \%)\end{array}$ & $\begin{array}{l}227 \\
(12 \%)\end{array}$ & $\begin{array}{l}237 \\
(12.5 \%)\end{array}$ & $\begin{array}{l}242 \\
(12.8 \%)\end{array}$ & $\begin{array}{l}248 \\
(13.1 \%)\end{array}$ & $2.7 \%$ \\
\hline $\begin{array}{l}\text { Congestive heart } \\
\text { failure }\end{array}$ & $\begin{array}{l}150 \\
(7.9 \%)\end{array}$ & $\begin{array}{l}165 \\
(8.7 \%)\end{array}$ & $\begin{array}{l}180 \\
(9.5 \%)\end{array}$ & $\begin{array}{l}197 \\
(10.4 \%)\end{array}$ & $\begin{array}{l}203 \\
(10.7 \%)\end{array}$ & $\begin{array}{l}207 \\
(10.9 \%)\end{array}$ & $3.0 \%$ \\
\hline Stroke & $\begin{array}{l}142 \\
(7.5 \%)\end{array}$ & $\begin{array}{l}159 \\
(8.4 \%)\end{array}$ & $\begin{array}{l}179 \\
(9.5 \%)\end{array}$ & $\begin{array}{l}188 \\
(9.9 \%)\end{array}$ & $\begin{array}{l}195 \\
(10.3 \%)\end{array}$ & $\begin{array}{l}199 \\
(10.5 \%)\end{array}$ & $3.0 \%$ \\
\hline $\begin{array}{l}\text { Peripheral vascular } \\
\text { disease }\end{array}$ & $\begin{array}{l}50 \\
(2.6 \%)\end{array}$ & $\begin{array}{l}56 \\
(3.0 \%)\end{array}$ & $\begin{array}{l}60 \\
(3.2 \%)\end{array}$ & $\begin{array}{l}65 \\
(3.4 \%)\end{array}$ & $\begin{array}{l}69 \\
(3.6 \%)\end{array}$ & $\begin{array}{l}69 \\
(3.6 \%)\end{array}$ & $1.0 \%$ \\
\hline $\begin{array}{l}\text { Severe } \\
\text { hypoglycemia }\end{array}$ & $\begin{array}{l}260 \\
(13.7 \%)\end{array}$ & $\begin{array}{l}287 \\
(15.2 \%)\end{array}$ & $\begin{array}{l}310 \\
(16.4 \%)\end{array}$ & $\begin{array}{l}320 \\
(16.9 \%)\end{array}$ & $\begin{array}{l}328 \\
(17.3 \%)\end{array}$ & $\begin{array}{l}334 \\
(17.6 \%)\end{array}$ & $3.9 \%$ \\
\hline $\begin{array}{l}\text { Chronic lung } \\
\text { disease }\end{array}$ & $\begin{array}{l}87 \\
(4.6 \%)\end{array}$ & $\begin{array}{l}91 \\
(4.8 \%)\end{array}$ & $\begin{array}{l}100 \\
(5.3 \%)\end{array}$ & $\begin{array}{l}105 \\
(5.5 \%)\end{array}$ & $\begin{array}{l}109 \\
(5.8 \%)\end{array}$ & $\begin{array}{l}112 \\
(5.9 \%)\end{array}$ & $1.3 \%$ \\
\hline $\begin{array}{l}\text { Chronic renal } \\
\text { disease }\end{array}$ & $\begin{array}{l}56 \\
(3.0 \%)\end{array}$ & $\begin{array}{l}70 \\
(3.7 \%)\end{array}$ & $\begin{array}{l}80 \\
(4.2 \%)\end{array}$ & $\begin{array}{l}94 \\
(5.0 \%)\end{array}$ & $\begin{array}{l}102 \\
(5.4 \%)\end{array}$ & $\begin{array}{l}106 \\
(5.6 \%)\end{array}$ & $2.6 \%$ \\
\hline
\end{tabular}


Figure 4 shows that percentages of patients in low $\mathrm{CCl}$ categories decreased, as patients proceed towards high $\mathrm{CCl}$ categories or death in each year. It was found that more percentages of control patients proceed towards $\mathrm{CCl}$ category of $\geq 5$ or death than surgical patients. Although more percentages of surgical patients died at 12 months, the growth rate of mortality for the surgery group was slower than that of the control group in the remaining years. Also, it was found that over half of surgical patients died from cancers and none of them died due to bariatric surgery at 12 months. Supplemental Table 5 summarizes the causes of death for both groups over the years.

\section{Discussion}

To our knowledge, the present study is the first population-based retrospective cohort study that estimated the five-year direct medical costs and comorbidities after bariatric surgery in Hong Kong. Above all, findings of this study provided additional information on direct medical costs in an Asian context, and provided basis for further cost-effectiveness analysis of bariatric surgery among obese Chinese patients with type 2 diabetes. Indeed, most existing costing analyses on bariatric surgery were conducted in the US [20-22], and those results may be inappropriate to be generalized to other jurisdictions, where mandatory insurance cover is not available and/or population ethnicities are totally different. Therefore, information on annual direct medical costs, healthcare utilization and medication use of bariatric patients provided by this study was especially important for policy makers and bariatric surgeons in Asian countries to further optimize the health resources allocation. Besides, comorbidity profiles of both groups were tracked for 60 months, providing an overview of changes of comorbidities. Also, as most previous comparative cost analyses on bariatric surgery did not include exploratory analyses $[20,22,36$, 37], this study also added current knowledge on medical costs of bariatric patients in subgroups, which allowed easy estimation of annual direct medical costs of surgical patients with different health conditions.

One major finding of the present study was that surgical patients had significantly higher medical costs in the year of surgery but had lower annual costs in the subsequent four years. This was mainly because surgical patients had great expenditures on bariatric procedures and bariatric surgery-related hospitalization, while control patients did not have such cost considerations. However, in the remaining years, shorter length of hospital stays were found in the surgery group in year 2 onwards. Indeed, coefficients in Supplemental Table 6 indicated that bariatric surgery was associated with increased medical costs in year $1(p<0.001)$. However, the values of coefficients were below zero in the following years, suggesting that bariatric surgery was associated with reduced medical costs. Despite the surgical patients having need to use outpatient and allied health professional services more frequently than nonsurgical patients over the years, the unit cost of hospitalization was much higher than that of outpatient visits and allied health professional visits. Consequently, the costs saved from outpatient and allied health services by the matched control group were considerably less than the extra costs of hospitalization, leading to the higher medical spending for the control group in the subsequent years. However, the finding that bariatric surgery was associated with reduced costs of inpatient services was inconsistent with the results of previous comparative studies [21,22,37], where higher hospitalization 
costs were reported in post-surgery periods. One possible explanation to this discrepancy is that reoperation rates of in patients with bariatric surgery was relatively low in Hong Kong. Indeed, the overall reoperation rate in the present surgical group was $4.74 \%$ in the index year and nearly zero in year 3 onwards (Supplemental Table 7). In comparison, reported re-operation rates in a systematic review is around $7 \%$ [38]. Besides, decreased frequencies of prescription and saved diabetes medication in the bariatric surgery group were observed in the first 4 years after bariatric surgery. Similar findings were also reported in previous studies, which suggested that the mean number of diabetes medication per patient and number of patients with prescriptions dropped after bariatric surgery over time $[20,39,40]$.

Though bariatric surgery had cost-saving effects in year 2 onwards, the five-year cumulative medical costs of surgical patients were higher than those of matched control patients, as saved costs failed to offset the increased costs due to bariatric surgery. However, the slope of the curve representing the cumulative costs of controls was steeper than that of surgical patients (Fig. 2), indicating that a possible break-even point may occur during the post-surgery period. Cumulative costs of surgical patients and controls were expected to converge at year 22 after the index date. In other words, cumulative medical costs of non-surgical patients would catch up those of surgical patients at year 22 if other conditions remain unchanged. However, as the baseline age of included patients in this study was around 53 , the cohorts would turn to 75 at the break-even year. Geriatric diseases that need intensive care may happen in their 70's and could incur more annual medical costs.

Of note, the relative differences of five-year cumulative costs between surgical and non-surgical patients were smaller in subgroups of patients who were female, had baseline age over 60 years old, had BMI over $35 \mathrm{~kg} / \mathrm{m}^{2}$, had diagnosis of type 2 diabetes over 5 years, had CCl greater than 4 , had history of CVD, and had history of CRD. These results implied shorter time to break-even may occur in these subgroups, and therefore obese type 2 diabetes patients in these subgroups were more suggested to undergo bariatric surgery. Notably, patients with CRD in the surgery group had similar 5-year cumulative medical costs with those in the control group. One possible explanation was that bariatric surgery has renal protective effects, even in patients with established renal diseases [38, 41, 42]. Improved renal function after bariatric surgery largely reduced the annual medical costs of surgical patients in post-surgery years, and facilitated cumulative costs of CRD patients with and without bariatric surgery approximately converge at year 5. Another possible reason was that treating CRD patients, especially those with end-stage renal disease, is costly [43]. Therefore, costs of bariatric operation for those patients accounted for $11.6 \%$ of the 5 -year total medical costs when compared to $36.3 \%$ of total costs in overall.

Our study also supported that bariatric surgery delayed the occurrence of most comorbidities and improved profiles of comorbidity, since fewer percentage of surgical patients proceed towards high $\mathrm{CCl}$ categories and surgical patients had lower mean $\mathrm{CCl}$ across 5 years. Particularly, bariatric surgery had protective effects on hypertension, hyperlipidemia, musculoskeletal and chronic orthopedic disorders, CVD, severe hypoglycemia, chronic lung disease and CRD. Indeed, previous studies have already reported that bariatric surgery was beneficial towards resolving or delaying above comorbidities $[9,38,42]$. 


\section{Limitations}

Several potential limitations in the present study should be acknowledged. Firstly, we included patients who had used HA healthcare services from 2006 to 2017. However, patients whose index year was 2014 or later have not yet completed their five-year follow-up. Consequently, the smaller sample size affected the estimation of annual medical costs in later years, and some findings should be interpreted with caution. Secondly, unlike a few previous studies [36], the present one did not differentiate the type of bariatric surgical procedures, but presented results in overall. Lastly, this study was based on the data obtained from HA, which is the public health service provider in Hong Kong. Hence, the annual direct medical costs of obese patients with type 2 diabetes attending private health services were not included.

\section{Conclusions}

To conclude, bariatric surgery was associated with significantly higher medical costs in the year of surgery and five-year cumulative costs, but was associated with reduced effects on medical costs in year 2 onwards. Although surgical patients had greater cumulative costs than controls at five years in overall and subgroups, bariatric surgery delayed the occurrence of most comorbidities.

\section{Abbreviations}

Accident and emergency (A\&E)

Charlson Comorbidity Index (CCl)

Cardiac care unit (CCU)

Clinical Management System (CMS)

Chronic Renal diseases (CRD)

Cardiovascular diseases (CVD)

Generalised linear models (GLMs)

General outpatient clinics (GOPC)

Hospital Authority (HA)

High dependency unit (HDU)

International Classification of Disease, Ninth Revision, Clinical Modification (ICD-9-CM) International Classification of Primary Care version 2 (ICPC-2)

Intensive care unit (ICU) 
Multiple imputation by chained equations (MICE)

Standardised mean difference (SMD)

Specialist outpatient clinics (SOPCs)

\section{Declarations}

\section{Ethical approval and consent to participate}

All procedures performed in studies involving human participants were in accordance with the ethical standards of the institutional and/or national research committee and with the 1964 Helsinki declaration and its later amendments or comparable ethical standards. Ethics approval of this study was granted by Institutional Review Board of the University of Hong Kong /Hospital Authority Hong Kong West Cluster (Ref No. UW 16-1018).

\section{Consent for publication}

Not applicable

\section{Availability of data and materials}

The data that support the findings of this study are available from Hong Kong Hospital Authority but restrictions apply to the availability of these data, which were used under license for the current study, and so are not publicly available. Data are however available from the authors upon reasonable request and with permission of Hong Kong Hospital Authority.

\section{Competing interests}

The authors declare that they have no competing interests.

\section{Funding}

This study was funded by Health and Medical Research Fund Research Fellowship Scheme, Food and Health Bureau, HKSAR (Ref No. \#02160087). URL:

https://rfs1.fhb.gov.hk/english/funds/funds_hmrf/funds_hmrf_type/funds_hmrf_type_rfel.html. The 
funder had no role in study design, data collection and analysis, decision to publish, or preparation of the manuscript.

\section{Authors' contributions}

Each author listed fulfils the authorship criteria and that no persons who have met these criteria have been omitted from the author list. CW conceived the study design. CW and TW collected data, performed the statistical analysis. TW drafted the manuscript. CW revised the manuscript. SW, BL, EG, OW, DT, DL, $\mathrm{EN}$ and $\mathrm{CL}$ evaluated the scientific validity and contributed to manuscript revisions. CW is the guarantor of this study. All authors contributed substantially and approved the final manuscript.

\section{Acknowledgements}

The authors wish to acknowledge the Central Panel on Administrative Assessment of External Data Requests, Hong Kong Hospital Authority Head Office, for the provision of data, and Mr Chu Wa Ho for statistical assistance.

\section{References}

1. Friedrich MJ: Global Obesity Epidemic Worsening. JAMA 2017, 318(7):603.

2. Collaborators GBDO, Afshin A, Forouzanfar MH, Reitsma MB, Sur P, Estep K, Lee A, Marczak L, Mokdad AH, Moradi-Lakeh $M$ et al: Health Effects of Overweight and Obesity in 195 Countries over 25 Years. N Engl J Med 2017, 377(1):13-27.

3. Cho NH, Shaw JE, Karuranga S, Huang Y, da Rocha Fernandes JD, Ohlrogge AW, Malanda B: IDF Diabetes Atlas: Global estimates of diabetes prevalence for 2017 and projections for 2045. Diabetes Res Clin Pract 2018, 138:271-281.

4. Withrow D, Alter DA: The economic burden of obesity worldwide: a systematic review of the direct costs of obesity. Obesity reviews 2011, 12(2):131-141.

5. Tsai AG, Williamson DF, Glick HA: Direct medical cost of overweight and obesity in the USA: a quantitative systematic review. Obesity Reviews 2011, 12(1):50-61.

6. Zimmet P, Alberti K: Surgery or medical therapy for obese patients with type 2 diabetes. $N$ Engl J Med 2012, 366(17):1635-1636.

7. Courcoulas AP, Belle SH, Neiberg RH, Pierson SK, Eagleton JK, Kalarchian MA, DeLany JP, Lang W, Jakicic JM: Three-Year Outcomes of Bariatric Surgery vs Lifestyle Intervention for Type 2 Diabetes 
Mellitus Treatment: A Randomized Clinical TrialBariatric Surgery vs Lifestyle Intervention for Type 2 Diabetes MellitusBariatric Surgery vs Lifestyle Intervention for Type 2 Diabetes Mellitus. JAMA Surgery 2015, 150(10):931-940.

8. Pontiroli AE, Laneri M, Veronelli A, Frige F, Micheletto G, Folli F, Adami G, Scopinaro N: Biliary pancreatic diversion and laparoscopic adjustable gastric banding in morbid obesity: their long-term effects on metabolic syndrome and on cardiovascular parameters. Cardiovasc Diabetol 2009, 8:37.

9. Buchwald H, Avidor Y, Braunwald E, Jensen MD, Pories W, Fahrbach K, Schoelles K: Bariatric surgery: a systematic review and meta-analysis. Jama 2004, 292(14):1724-1737.

10. Pontiroli AE, Zakaria AS, Mantegazza E, Morabito A, Saibene A, Mozzi E, Micheletto G, group Lw: Long-term mortality and incidence of cardiovascular diseases and type 2 diabetes in diabetic and nondiabetic obese patients undergoing gastric banding: a controlled study. Cardiovasc Diabetol 2016, 15:39.

11. Pontiroli AE, Zakaria AS, Fanchini M, Osio C, Tagliabue E, Micheletto G, Saibene A, Folli F: A 23-year study of mortality and development of co-morbidities in patients with obesity undergoing bariatric surgery (laparoscopic gastric banding) in comparison with medical treatment of obesity. Cardiovasc Diabetol 2018, 17(1):161.

12. Rubino F, Nathan DM, Eckel RH, Schauer PR, Alberti KG, Zimmet PZ, Del Prato S, Ji L, Sadikot SM, Herman WH et al: Metabolic Surgery in the Treatment Algorithm for Type 2 Diabetes: A Joint Statement by International Diabetes Organizations. Diabetes Care 2016, 39(6):861-877.

13. American Diabetes Association: 8. Obesity Management for the Treatment of Type 2 Diabetes: Standards of Medical Care in Diabetes-2019. Diabetes Care 2019, 42(Suppl 1):S81-S89.

14. National Institute for Health and Care Excellence: Obesity: identification, assessment and management of overweight and obesity in children, young people and adults. In.; 2014.

15. Welbourn R, Hollyman M, Kinsman R, Dixon J, Liem R, Ottosson J, Ramos A, Våge V, Al-Sabah S, Brown W: Bariatric surgery worldwide: baseline demographic description and one-year outcomes from the fourth IFSO global registry report 2018. Obesity surgery 2018:1-14.

16. Welbourn R, le Roux CW, Owen-Smith A, Wordsworth S, Blazeby JM: Why the NHS should do more bariatric surgery; how much should we do? BMJ 2016, 353:i1472.

17. Doble B, Wordsworth S, Rogers C, Welbourn R, Byrne J, Blazeby J: What Are the Real Procedural Costs of Bariatric Surgery? A Systematic Literature Review of Published Cost Analyses. OBES SURG 2017, 27(8):2179-2192.

18. Sun Y, You W, Almeida F, Estabrooks P, Davy B: The effectiveness and cost of lifestyle interventions including nutrition education for diabetes prevention: a systematic review and meta-analysis. Journal of the Academy of Nutrition and Dietetics 2017, 117(3):404-421. e436.

19. Terranova L, Busetto L, Vestri A, Zappa MA: Bariatric surgery: cost-effectiveness and budget impact. Obesity surgery 2012, 22(4):646-653.

20. Makary MA, Clark JM, Shore AD, Magnuson TH, Richards T, Bass EB, Dominici F, Weiner JP, Wu AW, Segal JB: Medication utilization and annual health care costs in patients with type 2 diabetes 
mellitus before and after bariatric surgery. Arch Surg 2010, 145(8):726-731.

21. Bleich SN, Chang HY, Lau B, Steele K, Clark JM, Richards T, Weiner JP, Wu AW, Segal JB: Impact of bariatric surgery on health care utilization and costs among patients with diabetes. Med Care 2012, 50(1):58-65.

22. Weiner JP, Goodwin SM, Chang HY, Bolen SD, Richards TM, Johns RA, Momin SR, Clark JM: Impact of bariatric surgery on health care costs of obese persons: a 6-year follow-up of surgical and comparison cohorts using health plan data. JAMA Surg 2013, 148(6):555-562.

23. Wu T, Wong SKH, Law BTT, Grieve E, Wu O, Tong DKH, Leung DKW, Lam CLK, Wong CKH: Five-year effectiveness of bariatric surgery on disease remission, weight loss, and changes of metabolic parameters in obese patients with type 2 diabetes: A population-based propensity score-matched cohort study. Diabetes Metab Res Rev 2020:e3236.

24. Kasama K, Mui W, Lee W, Lakdawala M, Naitoh T, Seki Y, Sasaki A, Wakabayashi G, Sasaki I, Kawamura I et al: IFSO-APC Consensus Statements 2011. OBES SURG 2012, 22(5):677-684.

25. Hospital Authority Ordiance (Chapter 113) Revision to Lists of Charges: Public Charges - Non-Eligible Persons [http://www.ha.org.hk/haho/ho/cs/238767_en.pdf]

26. List of private services - operations [http://www3.ha.org.hk/fnc/Operations.aspx? lang=ENG\&searchkeyword=plication\%20of\%20greater\%20curve]

27. Tran KL, Park YI, Pandya S, Muliyil NJ, Jensen BD, Huynh K, Nguyen QT: Overview of Glucagon-Like Peptide-1 Receptor Agonists for the Treatment of Patients with Type 2 Diabetes. Am Health Drug Benefits 2017, 10(4):178-188.

28. Royston P, White IR: Multiple Imputation by Chained Equations (MICE): Implementation in Stata. Journal of Statistical Software 2011, 45(4).

29. White I, Royston P, Wood A: Multiple imputation using chained equations: Issues and guidance for practice. Statistics in Medicine 2011, 30(4):377.

30. Austin PC: An Introduction to Propensity Score Methods for Reducing the Effects of Confounding in Observational Studies. Multivariate Behav Res 2011, 46(3):399-424.

31. Gregori D, Petrinco M, Bo S, Desideri A, Merletti F, Pagano E: Regression models for analyzing costs and their determinants in health care: an introductory review. Int J Qual Health C 2011, 23(3):331341.

32. Malehi AS, Pourmotahari F, Angali KA: Statistical models for the analysis of skewed healthcare cost data: a simulation study. Health Econ Rev 2015, 5:11.

33. Wong CKH, Jiao F, Tang EHM, Tong T, Thokala P, Lam CLK: Direct medical costs of diabetes mellitus in the year of mortality and year preceding the year of mortality. Diabetes Obes Metab 2018, 20(6):1470-1478.

34. Morrison RS, Penrod JD, Cassel JB, Caust-Ellenbogen M, Litke A, Spragens L, Meier DE, Palliative Care Leadership Centers' Outcomes G: Cost savings associated with US hospital palliative care consultation programs. Arch Intern Med 2008, 168(16):1783-1790. 
35. Manning WG, Mullahy J: Estimating log models: to transform or not to transform? Journal of health economics 2001, 20(4):461-494.

36. Lewis KH, Zhang F, Arterburn DE, Ross-Degnan D, Gillman MW, Wharam JF: Comparing Medical Costs and Use After Laparoscopic Adjustable Gastric Banding and Roux-en-Y Gastric Bypass. JAMA Surg 2015, 150(8):787-794.

37. Maciejewski ML, Smith VA, Livingston EH, Kavee AL, Kahwati LC, Henderson WG, Arterburn DE: Health care utilization and expenditure changes associated with bariatric surgery. Med Care 2010, 48(11):989-998.

38. Chang SH, Stoll CR, Song J, Varela JE, Eagon CJ, Colditz GA: The effectiveness and risks of bariatric surgery: an updated systematic review and meta-analysis, 2003-2012. JAMA Surg 2014, 149(3):275287.

39. Hodo DM, Waller JL, Martindale RG, Fick DM: Medication use after bariatric surgery in a managed care cohort. Surg Obes Relat Dis 2008, 4(5):601-607.

40. Segal JB, Clark JM, Shore AD, Dominici F, Magnuson T, Richards TM, Weiner JP, Bass EB, Wu AW, Makary MA: Prompt reduction in use of medications for comorbid conditions after bariatric surgery. Obes Surg 2009, 19(12):1646-1656.

41. Neff KJ, Frankel AH, Tam FW, Sadlier DM, Godson C, le Roux CW: The effect of bariatric surgery on renal function and disease: a focus on outcomes and inflammation. Nephrol Dial Transplant 2013, 28 Suppl 4:iv73-82.

42. Li K, Zou J, Ye Z, Di J, Han X, Zhang H, Liu W, Ren Q, Zhang P: Effects of Bariatric Surgery on Renal Function in Obese Patients: A Systematic Review and Meta Analysis. PLoS One 2016, 11(10):e0163907.

43. Wong CKH, Chen J, Fung SKS, Mok MMY, Cheng YL, Kong I, Lo WK, Lui SL, Chan TM, Lam CLK: Direct and indirect costs of end-stage renal disease patients in the first and second years after initiation of nocturnal home haemodialysis, hospital haemodialysis and peritoneal dialysis. Nephrol Dial Transplant 2019, 34(9):1565-1576.

\section{Figures}


Figure 1 Frequency of health utilization for patients in bariatric surgery and control groups in the index year and subsequent four years
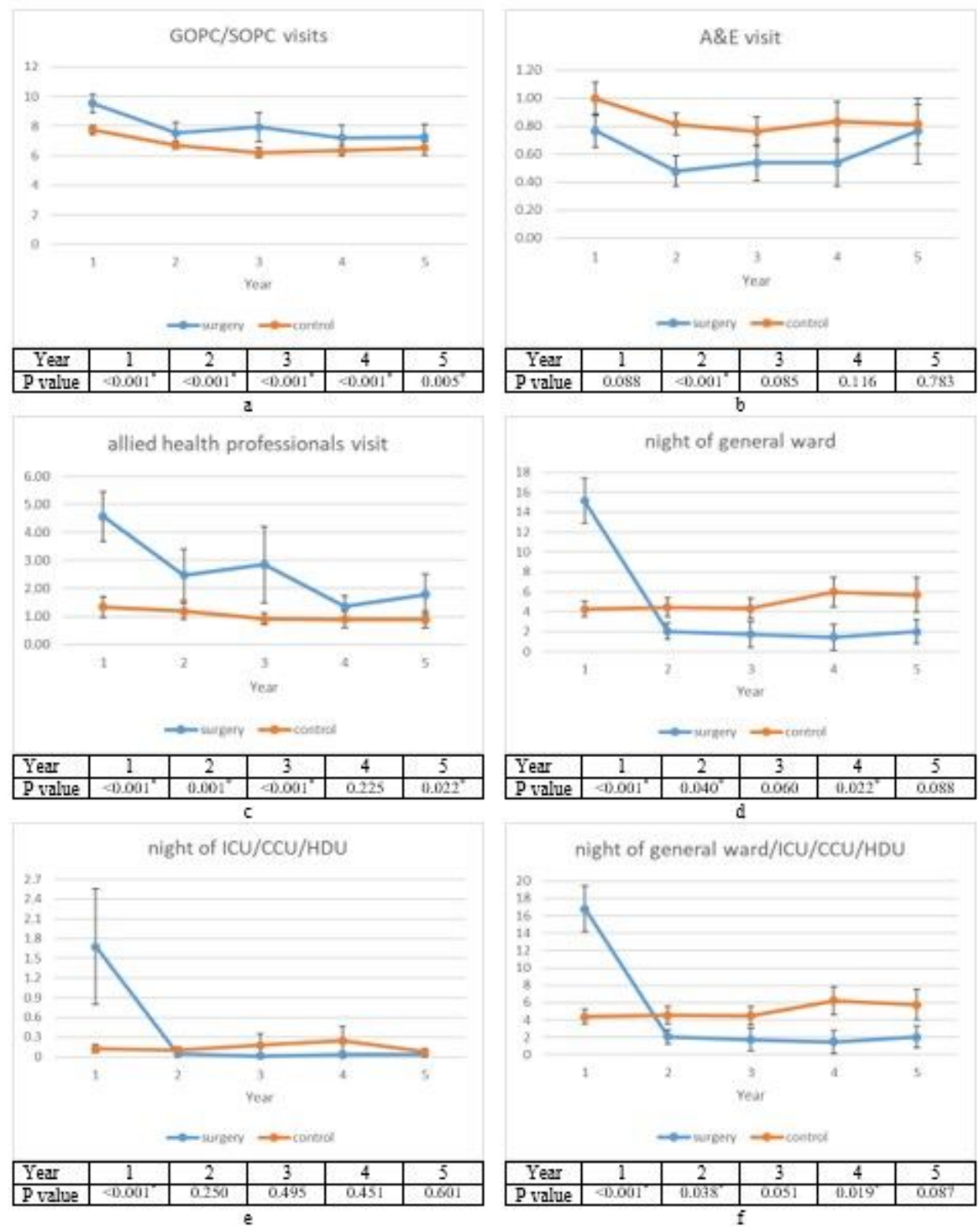

Notes: $\mathrm{GOPC}=$ general outpatient clinic; SOPC = specialist outpatient clinic; $\mathrm{A} \& \mathrm{E}=$ accidest $\&$ emergency department; $I C U=$ intensive care unit; $\mathrm{CCU}$ = cardiac care unit; $\mathrm{HDU}=$ high dependency unit

\section{Figure 2}

Frequency of health utilization for patients in bariatric surgery and control groups in the index year and subsequent four years. 

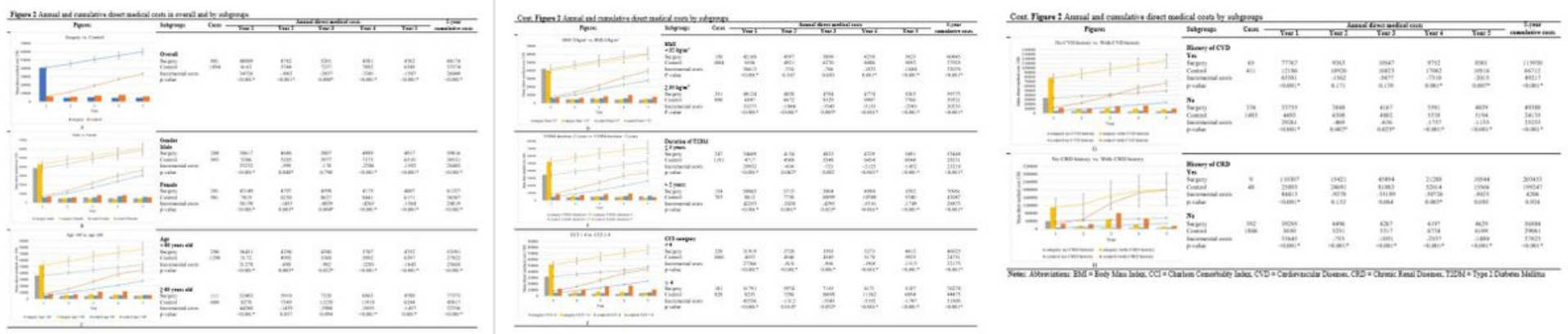

\section{Figure 3}

Annual and cumulative direct medical costs in overall and by subgroups: A) surgery vs. control; B) male vs. female; C) $<60$ years old vs. $\geq 60$ years old; D) BMl $<35 \mathrm{~kg} / \mathrm{m} 2$ vs BMl $\geq 35 \mathrm{~kg} / \mathrm{m} 2 ; \mathrm{E}$ ) T2DM duration $\leq 5$ years vs. T2DM duration $>5$ years; $F$ ) $\mathrm{CCl}<4$ vs. $\mathrm{CCl} \geq 4 ; \mathrm{G}$ ) No CVD history vs. with CVD history; $\mathrm{H}$ ) No CRD history vs. with CRD history

Figure 3 Changes of mean Charlson Comorbidity Index (CCI) of surgical and control patients over five years

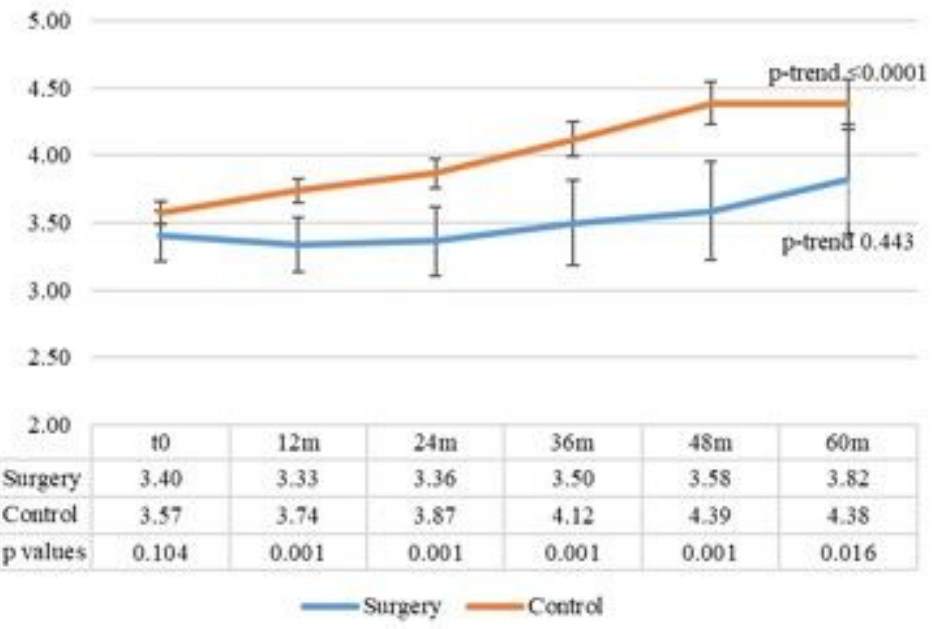

\section{Figure 5}

Changes of mean Charlson Comorbidity Index (CCl) of surgical and control patients over five years 
Figure 4 Percentage of surgical and control patients in different Charlson Comorbidity Index (CCI) categories

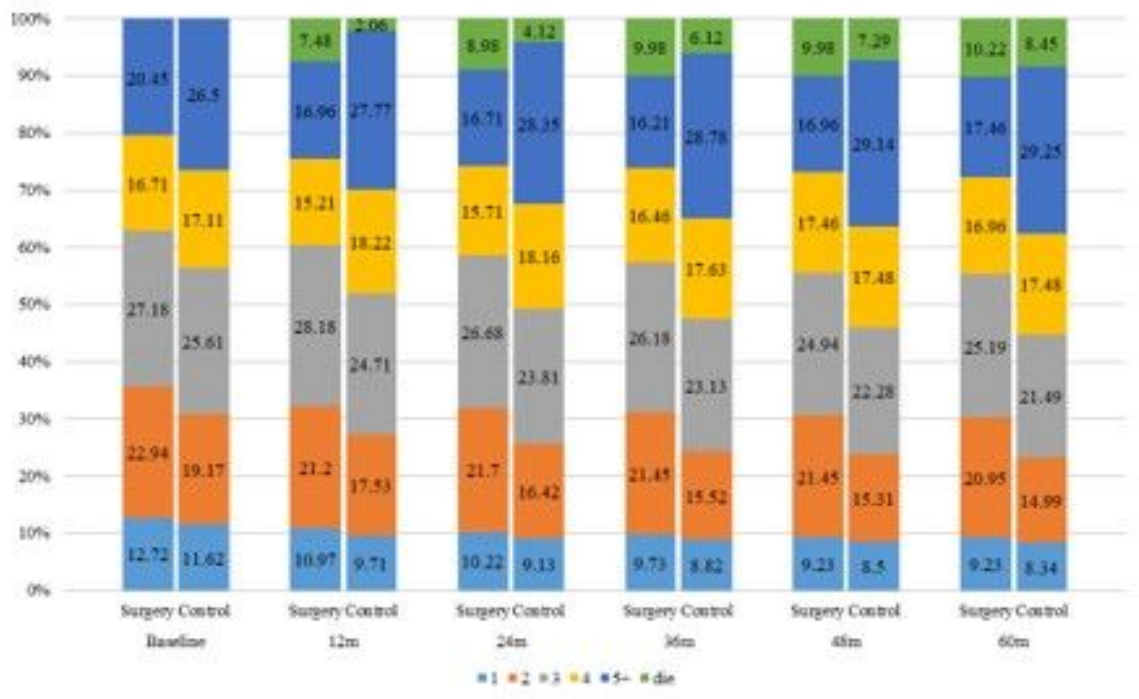

\section{Figure 7}

Percentage of surgical and control patients in different Charlson Comorbidity Index (CCl) categories

\section{Supplementary Files}

This is a list of supplementary files associated with this preprint. Click to download.

- Supplementalmaterials20200227.docx

- Supplementalmaterials20200227.docx 